\title{
The Role of Pest Control Advisers in Preventative Management of Grapevine Trunk Diseases
}

\author{
Vicken Hillis, Mark Lubell, Jonathan Kaplan, David Doll, and Kendra Baumgartner
}

First and second authors: Department of Environmental Science \& Policy, University of California, One Shields Avenue, Davis, CA 95616; third author: Department of Economics, California State University Sacramento, 6000 J. Street, Sacramento, CA 95819; fourth author: University of California Cooperative Extension, 2145 Wardrobe Avenue, Merced, CA 95341; and fifth author: U.S. Department of AgricultureAgricultural Research Service, Davis, CA 95616.

Accepted for publication 23 November 2015.

\begin{abstract}
Hillis, V., Lubell, M., Kaplan, J., Doll, D., and Baumgartner, K. 2016. The role of pest control advisers in preventative management of grapevine trunk diseases. Phytopathology 106:339-347.

Vineyards with trunk diseases (Botryosphaeria dieback, Esca, Eutypa dieback, and Phomopsis dieback) can have negative returns in the long run. Minimizing economic impacts depends on effective management, but adopting a preventative practice after infection occurs may not improve yields. Pest control advisers may reduce grower uncertainty about the efficacy of and need for prevention, which often entails future and unobservable benefits. Here, we surveyed advisers in California to examine their influence over grower decision-making, in the context of trunk diseases, which significantly limit grape production and for which

curative practices are unavailable. Our online survey revealed adviser awareness of high disease incidence, and reduced yields and vineyard lifespan. Advisers rated both preventative and postinfection practices positively. Despite higher cost estimates given to postinfection practices, advisers did not recommend preventative practices at higher rates. High recommendation rates were instead correlated with high disease incidence for both preventative and postinfection practices. Recommendation rates declined with increasing cost for preventative, but not for postinfection, practices. Our findings suggest that even when advisers acknowledge the risks of trunk diseases, they may not recommend preventative practices before infection occurs. This underscores the importance of clear outreach, emphasizing both the need for prevention and its long-term cost efficacy.
\end{abstract}

Crop diseases are a major constraint to agriculture, with total crop losses due to plant disease estimated at approximately $16 \%$ of global production (Oerke 2006). Producers often operate in highly competitive markets with slim profit margins and crop losses from diseases can result in significant economic losses. Diseased crops also reduce the ratio of yield to ecosystem services (or disservices) provided by agriculture, by reducing the number or density of plants in an agroecosystem and by necessitating disease management activities (e.g., pesticide applications and tillage), which can sometimes negate such services (Cheatham et al. 2009). Further, agroecosystems can be a source of pathogen spillover into natural ecosystems (Travadon and Baumgartner 2015). The challenges and consequences of crop diseases are likely to persist and may indeed worsen, due to increasing anthropogenic environmental change that drives pathogen pollution, the further intensification of agriculture required to feed a growing global population, and an increasingly globalized trade network for plant-based commodities that drives disease transmission (Anderson et al. 2004).

Integrated pest management (IPM), or the integration of biological, chemical, and cultural management practices, has long been considered a cost-effective means of disease management (Jacobsen 1997). When curative practices are unavailable, more costly, or more toxic, IPM favors the use of preventative practices.

Corresponding author: K. Baumgartner;

E-mail address: Kendra.Baumgartner@ars.usda.gov

*The $\boldsymbol{e}$-Xtra logo stands for "electronic extra" and indicates that one supplementary file is published online.

http://dx.doi.org/10.1094/PHYTO-10-15-0250-R

This article is in the public domain and not copyrightable. It may be freely reprinted with customary crediting of the source. The American Phytopathological Society, 2016.
To prevent disease outbreaks, a core tenet of IPM is proper timing of a management practice, whether it is meant to attack a pathogen at a vulnerable stage of its life cycle or to protect a susceptible stage of the plant's life cycle. IPM also emphasizes consideration of management efficiency, in terms of disease control efficacy, economic cost, and the risks a pathogen and its management pose to human and environmental health. Grower adoption of IPM strategies can be slow, however, in part due to a steep learning curve (Zalucki et al. 2009). With the seemingly constant introduction of new diseases, new scientific developments on the biology and spread of pathogens, and testing of new management practices, growers must rely on dependable information sources when deciding which practices to adopt.

Grower adoption of new farming practices is influenced by many factors, ranging from agroclimatic and market-related influences (Feder and Umali 1993) to a farmer's own perceptions and ideals (Adesina and Baidu-Forson 1995; Prokopy et al. 2008). In general, farmers readily adopt practices if the benefits clearly outweigh the costs (Lubell et al. 2011). Adoption is not as clear-cut, however, for practices with benefits that are difficult to observe or are spread out over long periods of time (Rogers 2003). Both characteristics can apply to practices used in perennial cropping systems for prevention of diseases with a long latent period or diseases that become more severe with crop age (e.g., Eastern filbert blight [Johnson et al. 1996], Bitter rot of apple [Creemers 2014], and Panicle blight of pistachio [Michailides and Morgan 2004]). The long-term nature of the disease cycle may make it difficult to rely on experiential learning in managing disease risk; trial-and-error would take years to evaluate an individual practice, thereby limiting a grower's opportunities to compare and contrast different practices. In such instances, we might expect that farmers rely more heavily on social learning, or using information from others, to guide their decision making as this would be a more direct route toward solving the problem. 
The ways in which farmers incorporate social information into their decision making has been shown to have important implications for how they manage the risk of invasive diseases (Breukers et al. 2012) and their adoption of IPM practices (Sherman and Gent 2014). Within any particular social network, specific individuals are more or less crucial to the effective flow of information. Individuals with an advisory role (e.g., university cooperative extension farm advisors and extension specialists) are important in such networks in shaping the content and flow of information (e.g., vineyard management practices [Hoffman et al. 2015]). Cooperative extension personnel can, for some topics, serve as key conduits of information because they are connected to a disproportionately higher number of individuals. They can also play an important role within the network as boundary spanners, linking relatively unconnected groups of farmers who otherwise would not share information.

Another group of advisers known to influence IPM adoption in a variety of crops are pest control advisers (PCAs) (Hurd 1994; Ridgley and Brush 1992; Shennan et al. 2001). As licensed professionals, they must have university training in IPM. PCAs consult in fields of different ages, planted with cultivars of different susceptibility, and in different microclimates, all of which are factors that influence disease incidence, in general. This greater range of experience gives a PCA different perspectives on disease management than a grower may have from farming a single field.

Here we examine the role of PCAs in the adoption of management practices for the trunk diseases Botryosphaeria dieback, Esca, Eutypa dieback, and Phomopsis dieback in California vineyards (Fig. 1). Vineyards are long-term cropping systems, with properly managed vineyards potentially producing for many decades. In this study system, preventative practices are particularly important because the

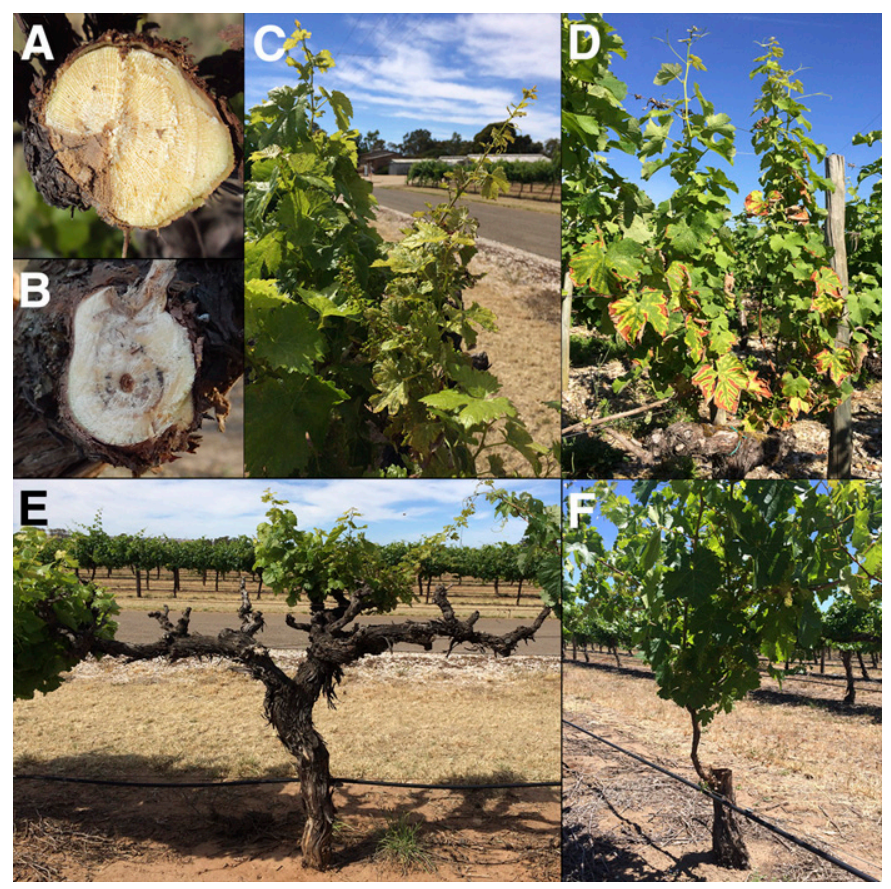

Fig. 1. Symptoms of grapevine trunk diseases: Botryosphaeria dieback (main causal fungus Neofusicoccum parvum), Esca (Phaeoacremonium minimum and Phaeomoniella chlamydospora), Eutypa dieback (Eutypa lata), and Phomopsis dieback (Diaporthe ampelina). The disease cycle starts with infection of a pruning wound by fungal spores, after which a chronic infection develops in the wood. Depending on the trunk disease, the symptoms of this infection can appear in infected wood (in cross section) $\mathbf{A}$, as a V-shaped wood canker or B, as concentric rings of black spots. Because such wood symptoms are internal, trunk diseases do not become apparent until development of canopy symptoms, such as $\mathbf{C}$, the stunted and deformed leaves caused by Eutypa dieback or $\mathbf{D}$, the interveinal chlorosis and necrosis caused by Esca. E, Trunk diseases eventually kill fruiting positions. F, The only way to eradicate trunk pathogens is to cut out infected wood and to retrain a new vine from the base of the trunk, a type of vine surgery referred to in this manuscript as "retrain trunk." diseases are widespread (Úrbez-Torres et al. 2006) and cause significant yield losses (Munkvold et al. 1994). For example, average yield losses due to Esca were measured at rates of up to $20 \%$ in French vineyards (Bruez et al. 2013). The economic consequences for the dieback-type trunk diseases to California wine grapes are estimated to amount to a $14 \%$ loss in revenue per year (Siebert 2001). Because trunk diseases are chronic and there is no way to eradicate the infections (short of replanting the vine or physically cutting away an infected cordon or trunk), foregoing prevention early in the disease cycle results in more yield losses later on (J. Kaplan, R. Travadon, M. L. Cooper, V. Hillis, M. Lubell, and K. Baumgartner, unpublished data). Apart from direct costs to farmers, there are indirect impacts to agricultural and natural ecosystems of foregoing prevention, stemming from the fact that vineyards in which trunk diseases are left unchecked are less efficient in their production and are thus replanted prematurely. Vineyard establishment (and vineyard replanting) contributes a disproportionate share of fossil-fuel expenditures in the crop's lifetime energy budget (Smyth and Russell 2009). Moreover, new vineyards (in part a result of lessefficient vineyards) mean less natural habitat in California, for example, where vineyards in the North Coastal grape-growing region generally replace native oak woodlands (Merenlender 2000). Furthermore, as relatively flat, accessible land is increasingly occupied, new vineyards are established at higher elevations and on steeper slopes more prone to soil erosion (Merenlender 2000).

The multiyear cycles of trunk diseases make it particularly difficult for growers to use trial-and-error as a means of evaluating the efficacy of any one practice, thereby increasing the importance of other individuals in the agricultural knowledge network. PCAs make disease management recommendations, which may influence grower decisions (Brodt et al. 2007), and so in the case of trunk diseases we cannot fully understand grower perceptions and behavior without also understanding what advisers think. Because of their formal training in IPM and their work experience in many different vineyards, we expect PCAs, more so than growers, to (i) understand the relationship between vineyard age and disease pressure, (ii) be familiar with the entire range of management practices, and (iii) know the importance of timing practices for use on a preventative basis versus a postinfection basis. In order to evaluate the role of advisers in grower decision making for trunk disease management, we conducted an online survey, which examined (i) adviser opinion of the incidence and impact of trunk diseases, (ii) adviser perceptions of trunk disease management practices, (iii) adviser recommendation and grower implementation rates of the practices, and (iv) the key drivers of adviser recommendations, including their perceptions of disease control efficacy and practice cost.

\section{MATERIALS AND METHODS}

Survey design. We designed an online questionnaire targeted toward individuals who serve in an advisory capacity in disease management of grapes (wine, table, and raisin) (Supplementary File S1). This included mainly PCAs and, to a lesser extent, vineyard managers, vineyard consultants, and others with an advisory role. For convenience, we refer to all respondents as advisers for the remainder of the paper. The questionnaire asked introductory questions about background information of advisers (job type, years of experience, and California counties where they work) and the incidence of trunk diseases in the vineyards they work in. The main body of the questionnaire focused on a set of nine trunk disease management practices (Table 1). We asked advisers about their perceptions of the costs and benefits of the practices, as well as their recommendation rates and subsequent grower implementation rates for each practice. Lastly, the questionnaire asked about their information sources, and their participation in different agricultural organizations.

We conducted semistructured interviews with 22 individuals from various sectors of the grape industry (PCAs, vineyard 
consultants, growers, pesticide supplier representatives, and University of California Cooperative Extension (UCCE) Farm Advisors), California growing regions (Central Coast, North Coast, and Central Valley) and grape commodities (wine, table, and raisin grapes). The interviews focused on knowledge about and perceptions of trunk diseases and trunk disease management practices, as well as sources of learning and participation in outreach and education programs. Our survey advisory board consisted of UCCE Farm Advisors, representatives from national and regional grower groups, wine and table grape growers, and PCAs. Feedback from semistructured interviews and the survey advisory board helped ensure the reliability and validity of our survey questions, as well as their relevance to the stakeholder community.

Survey distribution. We distributed the survey between April and June 2013. In order to ensure broad coverage in our survey population, we implemented two distribution strategies. First, we distributed the survey to the active members of the California Association of PCAs (CAPCA) for grapes in all relevant areas of California (CAPCA regional chapters: Central Coast, Central Valley, Desert Valleys, Fresno-Madera, Kern, Monterey Bay, North Coast, SoCal, Tulare-Kings, and Woodland). This link was delivered to 1,380 PCAs and was opened by 612 PCAs (44\%), a higher percentage than CAPCA's usual communications of approximately 27 to $31 \%$. In order to boost our coverage and response, the survey was distributed by members of our survey advisory board, mainly to the constituencies of UCCE Viticulture Farm Advisors, and to the membership of two grower groups (Lodi Winegrape Commission and California Table Grape Commission). In the case of this second distribution strategy, the survey link was distributed to over 1,000 individuals through e-mail lists, placement on websites, announcements at in-person meetings, and advertisements in newsletters. Through both distribution strategies combined, 133 individuals completed the survey. We were unable to track a response rate for the second distribution strategy (and thus for the survey overall). We report demographic and other characteristics of our respondent sample (Table 2); our respondent sample includes broad coverage of wine grape advisers with respect to specific job category, geographic region, number and acreage of clients advised, years of experience in the industry, and percentage of time spent in the vineyard.
Statistical analyses. In analysis and interpretation of the results, practices were categorized as "preventative" or "postinfection," based on the point in the disease cycle they are expected to be most effective. As our survey was meant in part to evaluate relationships between timing of practice recommendation and other factors, such as disease incidence and practice cost efficacy, we did not categorize the practices as preventative or postinfection on the survey itself, so as not to potentially bias responses based on the practice categorizations alone. We consider "protectant-hand" and "protectant-tractor" to be preventative practices because their application to fresh pruning wounds has been shown to provide a protective barrier (Amponsah et al. 2012; Halleen et al. 2010; Pitt et al. 2012; Rolshausen and Gubler 2005; Rolshausen et al. 2010; Sosnowski et al. 2008, 2013). "Delayed pruning" and "double pruning" are preventative in that they minimize the risk of infection by being timed during a period of low susceptibility (Úrbez-Torres and Gubler 2011; Van Niekerk et al. 2011; Weber et al. 2007). "Retrain trunk" and "retrain cordon," which are both types of vine surgery, are applied to infected vines, hence their categorization as postinfection practices (Sosnowski et al. 2011). "Sanitation" involves physically cutting out infected spurs and cordons, but its efficacy has not been evaluated on an experimental basis. "Replant specific vines" and "replant whole block" are postinfection practices in the context of trunk disease management because they are meant to replace infected vines.

We examined the relationship between recommendation rate as a dependent variable and the following independent variables: disease incidence in the vineyards advisers service (0 to $100 \%$ symptomatic vines), adviser perceptions of disease control efficacy (scale of 1 [very ineffective] to 7 [very effective]), and their cost estimates of each practice (U.S. dollars per ha per year). We fit three separate linear multilevel models, each including one independent variable (incidence, efficacy, and cost). In each model, we included a categorical variable for practice category (preventative or postinfection) as well as an interaction effect between the independent variable and practice category. Finally, we included a random intercept for advisers in each model to account for the clustering of responses within advisers inherent to the data, since any given adviser provided nine different recommendation rates (one per practice). To visualize the results, we plotted predictions of

TABLE 1. Management practices for trunk diseases in California vineyards, as defined in our online survey of pest control advisers ${ }^{\mathrm{a}}$

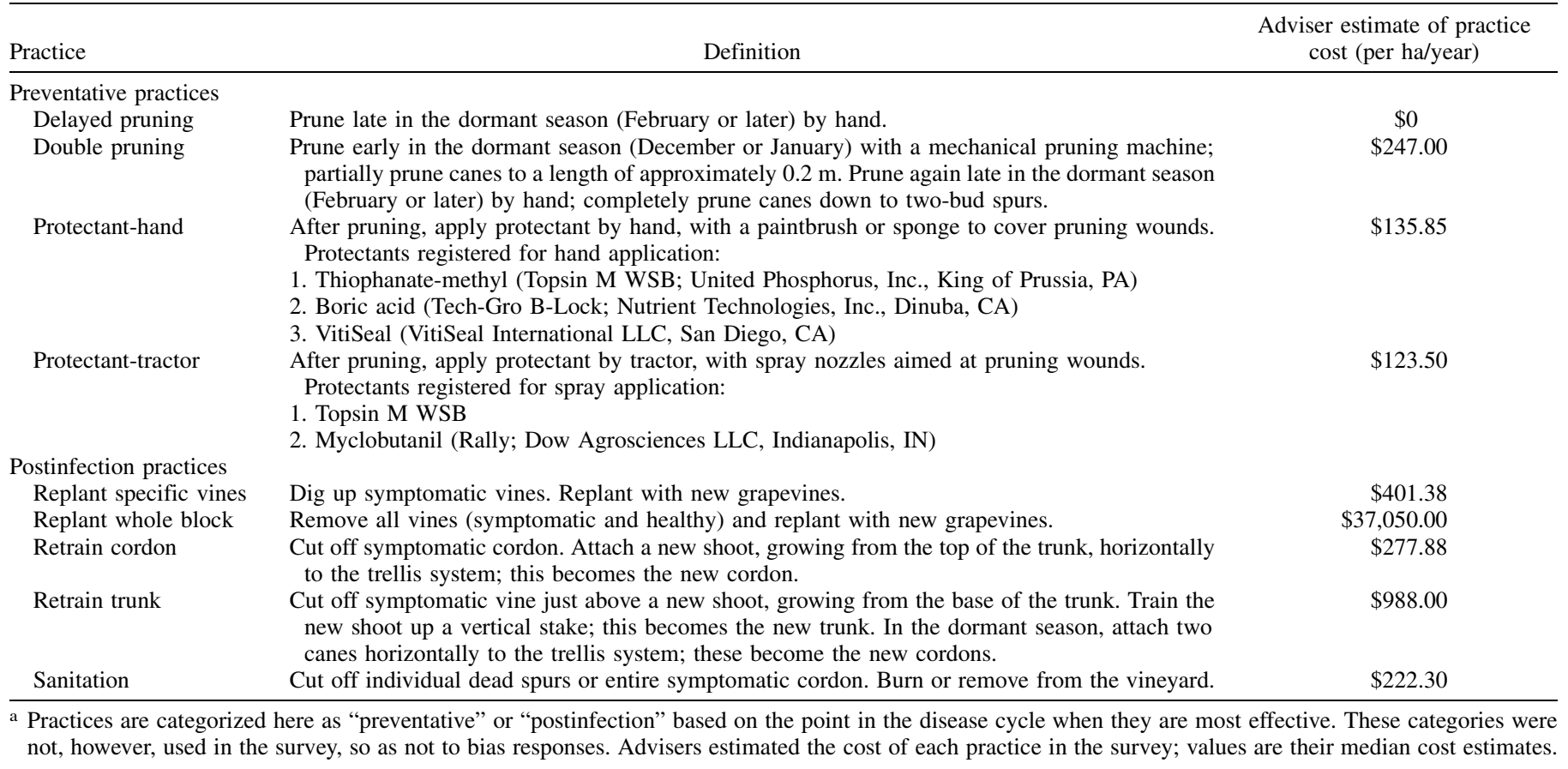


the probability of recommendation for an average preventative and postinfection practice from each model. We conducted all analyses in $\mathrm{R}$ version 3.2 .1 , using the base, lme4, rethinking, and ggplot2 packages (RCoreTeam 2013).

\section{RESULTS}

Adviser perceptions of the trunk disease problem. Overall, advisers indicate that trunk diseases are a substantial challenge to farmers, reporting that they are widespread, expensive to manage, and that they cause serious negative impacts to yield and the productive lifespan of the vineyard. Specifically, when asked to estimate the average percentage loss in yield due to trunk diseases in a mature vineyard, the median response was $17 \%$. Further, $25 \%$ of advisers reported average yield losses of $25 \%$ or greater, with two advisers claiming average losses of over $70 \%$. The median reported impact on lifespan was a loss of 15 years relative to the productive lifespan of a healthy vineyard, with $25 \%$ of advisers reporting a loss of 20 or more years. Advisers estimated that farmers spend an average of $\$ 447 /$ hectare-year to prevent and manage trunk diseases.

TABLE 2. Demographic and other characteristics of survey respondents ${ }^{\mathrm{a}}$

\begin{tabular}{lrc}
\hline Survey item & Responses & Percentage of total \\
\hline Job category & 131 & \\
Manufacturer & 7 & $5 \%$ \\
Private consultant & 22 & $17 \%$ \\
Dealer/distributor & 21 & $16 \%$ \\
Public agency & 3 & $2 \%$ \\
Farm management & 39 & $30 \%$ \\
Grower & 78 & $60 \%$ \\
Other & 12 & $9 \%$ \\
Years of experience & 130 & \\
Fewer than 15 & 47 & $36 \%$ \\
Greater than 15, fewer than 30 & 33 & $25 \%$ \\
Greater than 30, fewer than 45 & 40 & $31 \%$ \\
Greater than 45, fewer than 60 & 8 & $6 \%$ \\
Greater than 60 & 2 & $2 \%$ \\
Region & 124 & \\
Central Coast & 29 & $23 \%$ \\
North Coast & 47 & $38 \%$ \\
Northern San Joaquin Valley & 61 & $49 \%$ \\
Sacramento Valley & 29 & $23 \%$ \\
Sierra Foothills & 15 & $12 \%$ \\
Southern California & 9 & $7 \%$ \\
Southern San Joaquin Valley & 16 & $13 \%$ \\
Number of clients & 103 & \\
1 to 10 clients & 52 & $50 \%$ \\
50 or fewer clients & 35 & $34 \%$ \\
Greater than 50 clients & 16 & $16 \%$ \\
Acreage advised & 104 & $36 \%$ \\
Less than 1000 total acres & 37 & $28 \%$ \\
Greater than 1000, less than 5000 & 29 & $37 \%$ \\
Greater than 5000 & 38 & \\
Percent of time in vineyard & 105 & 27 \\
Less than 1/3 & 32 & $46 \%$ \\
Greater than 1/3, less than 2/3 & 46 & \\
Greater than 2/3 & & \\
\hline
\end{tabular}

${ }^{a}$ For job category and region, percentage of total column sums to greater than $100 \%$ because individuals could select more than one response. Regional affiliations were aggregated from county-level response and correspond to the total number of individuals working in counties within the region. Central Coast: Alameda, Contra Costa, Monterey, San Benito, San Francisco, San Luis Obispo, San Mateo, Santa Barbara, Santa Clara, Santa Cruz; North Coast: Humboldt, Lake, Marin, Mendocino, Modoc, Napa, and Sonoma; Northern San Joaquin Valley: Fresno, Kings, Madera, Merced, San Joaquin, and Stanislaus; Sacramento Valley: Butte, Colusa, Glenn, Sacramento, Shasta, Siskiyou, Solano, Sutter, Tehama, Yolo, and Yuba; Sierra Foothills: Alpine, Amador, Calaveras, El Dorado, Inyo, Mariposa, Mono, Nevada, Placer, Plumas, and Tuolumne; Southern California: Imperial, Los Angeles, Orange, Riverside, San Bernardino, San Diego, and Ventura; and Southern San Joaquin Valley: Kern and Tulare.
Common sources of information for advisers. We asked advisers, "How often do you use the following resources for learning about how best to manage trunk diseases?" The most common sources were advice from other PCAs, formal field trials, university publications, UCCE Farm Advisors, and trade journals (Fig. 2). The least common sources were newspapers/media, the state and county farm bureaus, and the county agricultural commissioner.

Recommendation rates and their determinants. In order to quantify recommendation rates for preventative and postinfection practices, we asked advisers, "What percentage of the time (0 to $100 \%$ ) do you recommend the following trunk disease management practices, when the opportunity arises?" In general, recommendation rates of preventative and postinfection practices were relatively similar. "Sanitation" was recommended the most of all nine practices (Fig. 3A). Least frequent was "replant whole block" at $15 \%$. For the two types of vine surgery, "retrain cordon" was recommended more often than "retrain trunk" (40\% versus $35 \%$, Fig. 3A). Among the four preventative practices, "delayed pruning" had the highest recommendation rate and "double pruning" had the lowest.

In order to quantify adviser perceptions of the benefits of trunk disease management, we asked "How effective are the following trunk disease management practices in addressing the issues associated with trunk diseases, either through preventing infection, reducing the spread of disease, mitigating yield loss, or in some other way?" We framed this question broadly to accommodate the range of control mechanisms among the practices. Advisers could select an answer ranging from 1 (very ineffective) to 7 (very effective). All practices had a mean rating of disease control efficacy above 5, suggesting that the majority of advisers perceived each practice as relatively effective (Fig. 4). "Sanitation" was rated least effective of all practices. On the opposite extreme, "replant whole block" was rated most effective. Between the two types of vine surgery, "retrain trunk" was perceived as more effective than "retrain cordon." Among the four preventative practices, "protectants" were perceived as most effective, whereas the two

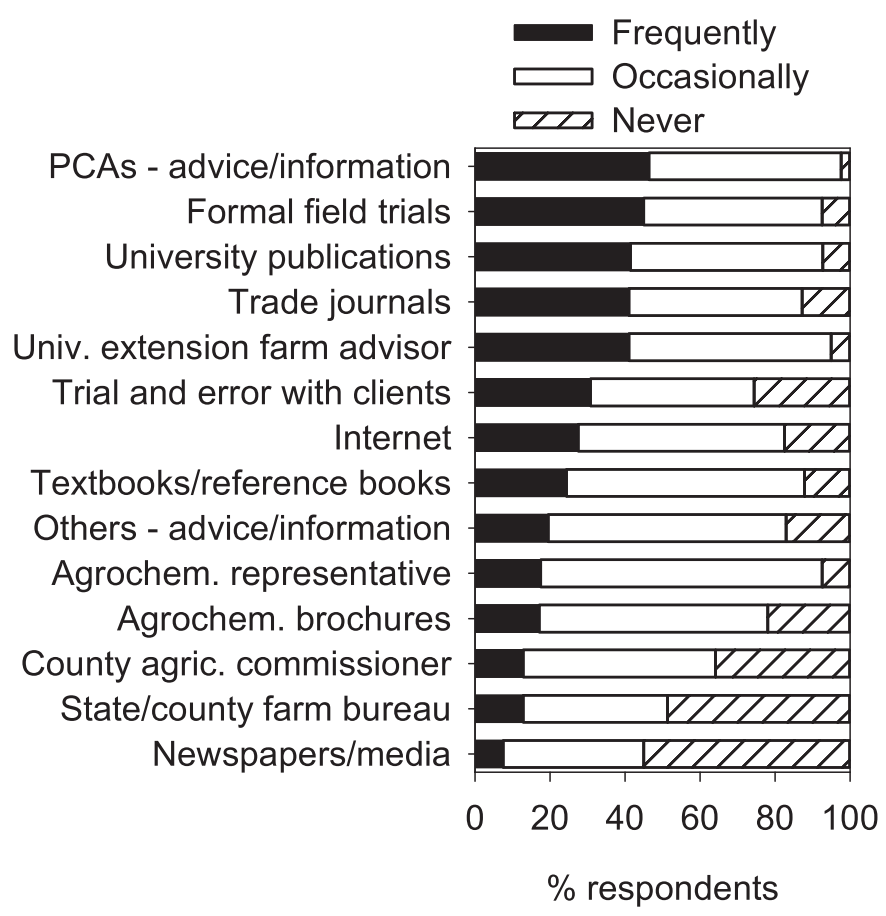

Fig. 2. Sources of information for trunk disease management, as rated by advisers in terms of the frequency of their use. Each bar displays the percentage of advisers who use each of the information sources frequently, occasionally, or never. Information sources are sorted in descending order of highest percentage of responses for frequently. 
pruning practices (“delayed pruning" and "double pruning") were rated lower. Between the two application methods for protectants, hand application was rated slightly higher than tractor application.

We asked advisers, "In your opinion, how much does it cost, if anything, for a client to implement the following trunk disease management practices?" Among the postinfection practices, "sanitation" was considered least expensive (Table 1). The most expensive postinfection practice was "replant whole block." Between the two types of vine surgery, "retrain trunk" was over three times the cost of "retrain cordon." Among the preventative practices, the least expensive was "delayed pruning," which had a cost estimate of $\$ 0$ because its cost is no different from that of early pruning (i.e., pruning in December, during the period of high disease risk). "Double pruning" was the most expensive preventative practice.

In order to assess the incidence of trunk diseases in the vineyards our respondents worked in we asked, "How prevalent are trunk diseases in the area that you service, given typical management practices currently being used." Respondents positioned a slider bar between 0 and $100 \%$ to indicate the percentage of vines displaying symptoms of infection. Advisers reported that trunk diseases are widespread in the areas they service, with over $25 \%$ estimating disease incidence levels of at least $38 \%$.

There was a strong positive relationship between recommendation rate and disease incidence (beta $=12.48, P=0.008$; Table 3 , Fig. 5A). While an adviser who reports little to no disease incidence is predicted to recommend a practice approximately $40 \%$ of the time, advisers whose vineyards are heavily diseased at rates approaching $100 \%$ will apply management practices at rates approaching 90\%. This relationship was similar for both preventative and postinfection practices; all practices were recommended at high rates for vineyards with high disease incidence. We also found a strong positive relationship between recommendation rate and perceived practice efficacy (beta $=6.61, P=0.01$; Table 3, Fig. 5B), for both preventative and postinfection practices. An adviser who rates a practice as "very ineffective" is likely to recommend the practice only $25 \%$ of the time, whereas an adviser who rates a practice as "very effective" is likely to promote a postinfection practice at a rate of approximately 55\% and a preventative practice at a rate of approximately $60 \%$.

We did not find an overall relationship between practice cost and recommendation rates (beta $=-0.73, P=0.70$; Table 3, Fig. 5C). However, we did find an interaction between practice category and the cost of the practice, such that there was a negative relationship between recommendation rate and practice cost for preventative practices, but not for postinfection practices. For practices that cost close to nothing, advisers are predicted to recommend the practice about $60 \%$ of the time, regardless of the type of practice. As costs increase, recommendation rates decline steeply for preventative practices. Recommendation rates for postinfection practices remain more or less constant, however, as costs increase.

Grower responses to adviser recommendations. To address grower implementation of adviser recommendations, albeit from the perspective of the advisers, we asked, "How often do clients tend to follow your recommendation to use the following trunk disease management practices?" Advisers reported that their recommendations were implemented at moderate to high rates for all practices

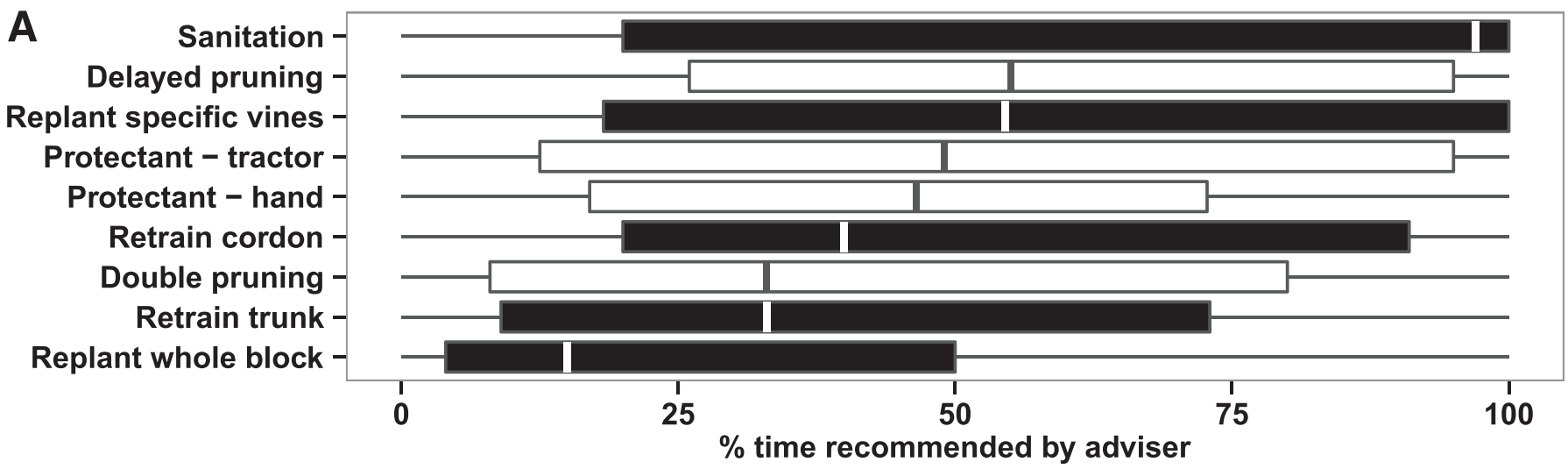

B

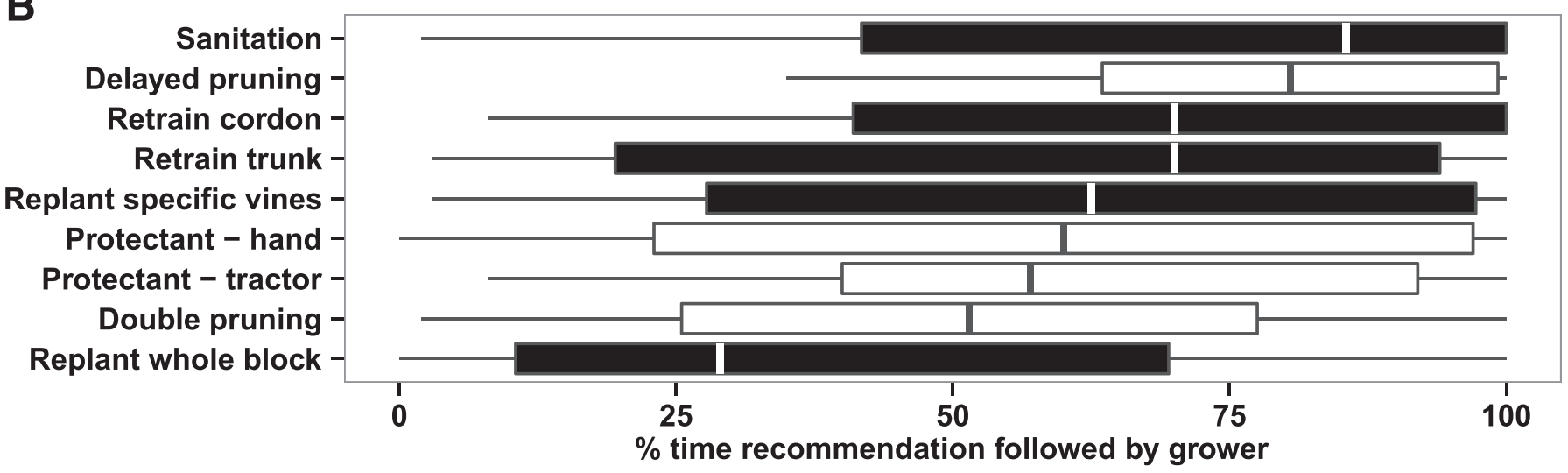

\section{Post-infection 自 Preventative}

Fig. 3. A, Rate at which advisers recommend practices and $\mathbf{B}$, perceived rate at which recommendations are implemented by growers, for each of the nine management practices. Vertical bars within the boxes represent medians; box edges indicate interquartile ranges (25th and 75th percentiles). The color of column reflects the practice category; postinfection practices are black and preventative practices are white. 
(between 40 and $80 \%$ on average; Fig. 3B). Implementation rates were similar to recommendation rates, with only slight relative differences. For example, the two types of vine surgery had almost identical implementation rates.

The survey attempted to address the possible reasons growers do not follow adviser recommendations, from the advisers' own perspectives, by asking them to select from among a list of prespecified reasons with the following prompt, "For each practice, which of the following are reasons that clients do not follow your recommendation?" Although these items suffered from substantial item nonresponse (each item received approximately 20 responses and thus too low for statistical analyses), we report them here because the answers tend to correspond to the indirect relationship we found between recommendation rate and estimated practice cost. For "delayed pruning," by far the most commonly cited reasons among those not adopting, albeit from the very few advisers who responded to this question, included high labor cost $(n=8)$ and unavailability of labor $(n=12)$. For "double pruning," which had the highest median cost estimate of all preventative practices ( $\$ 247$ per ha per year, Table 1), the main reason was that the practice is considered too expensive generally $(n=15)$, particularly with regard to the cost of labor $(n=14)$. For "protectants," general expense was also an important barrier $(n=18)$, but a substantial proportion of the responses also indicated a concern with the efficacy of the practice $(n=9)$. Finally, for all postinfection practices, by far the most common reason for not adopting the practice was cost ( $n>22$ for "retrain cordon" and "retrain trunk," $n>18$ for "replant specific vines" and "replant whole block"). For all practices, preventative and postinfection, decreases in yield or crop quality were not commonly cited as reasons for nonadoption ( $n<4$ for all practices and items).

\section{DISCUSSION}

Our survey demonstrates that advisers acknowledge both the high likelihood of a vineyard contracting trunk diseases in California and the resulting negative impacts to yield and lifespan. Understanding how advisers incorporate both the probability of disease and the costs of their decisions is important because both the probability and cost dimensions of risk shape the adoption of new disease management practices (McRoberts et al. 2011). Adviser perceptions of disease control efficacy for several practices corresponded to results that have been previously documented in university publications and formal field trials, both of which advisers ranked within their top five sources of information on trunk disease management. For example, the higher efficacy rating advisers gave to "retrain trunk" compared with "retrain cordon" corresponds to empirical evidence on the relative efficacy of these two types of vine

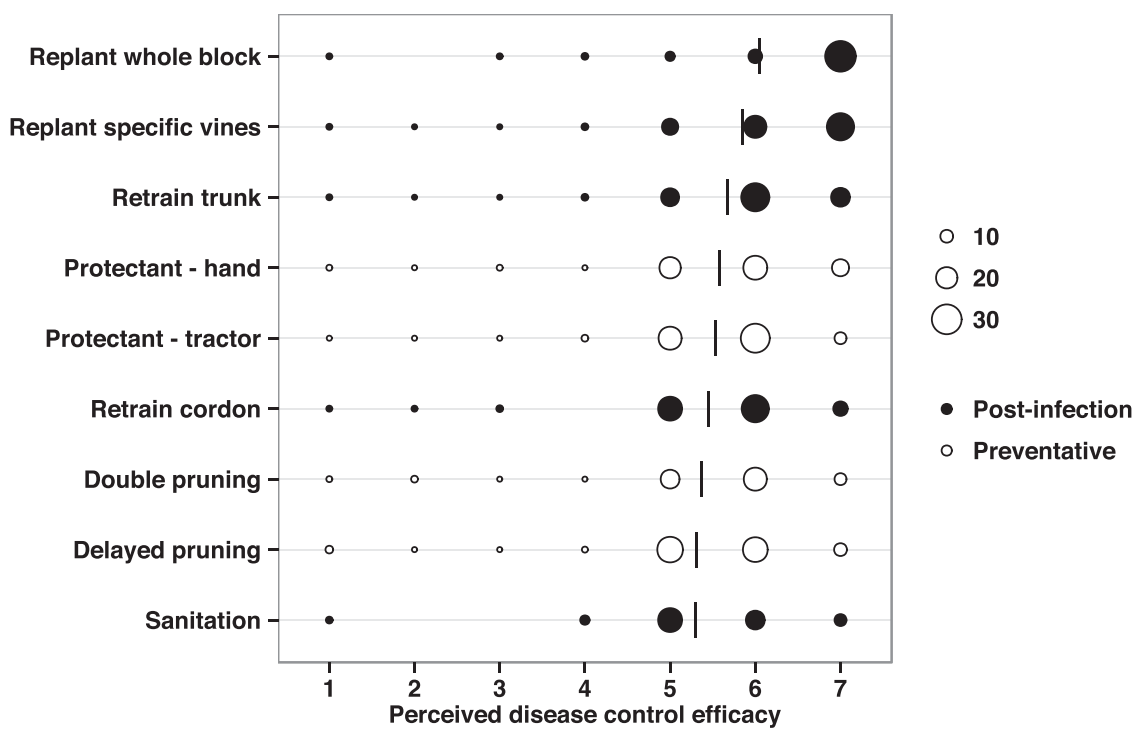

Fig. 4. Perceived disease control efficacy of nine management practices, based on ratings by advisers on a scale of 1 (very ineffective) to 7 (very effective). Bars represent means; size of circles is proportional to the number of advisers selecting a given rating for a given practice. The color of circle reflects the practice category; postinfection practices are black and preventative practices are white.

TABLE 3. Estimated parameter coefficients, standard errors, and associated $P$ values for fixed effects in each of the three linear multilevel models, used to examine the relationship between recommendation rate (dependent variable) and three independent variables: disease incidence, disease control efficacy, and practice cost ${ }^{\mathrm{a}}$

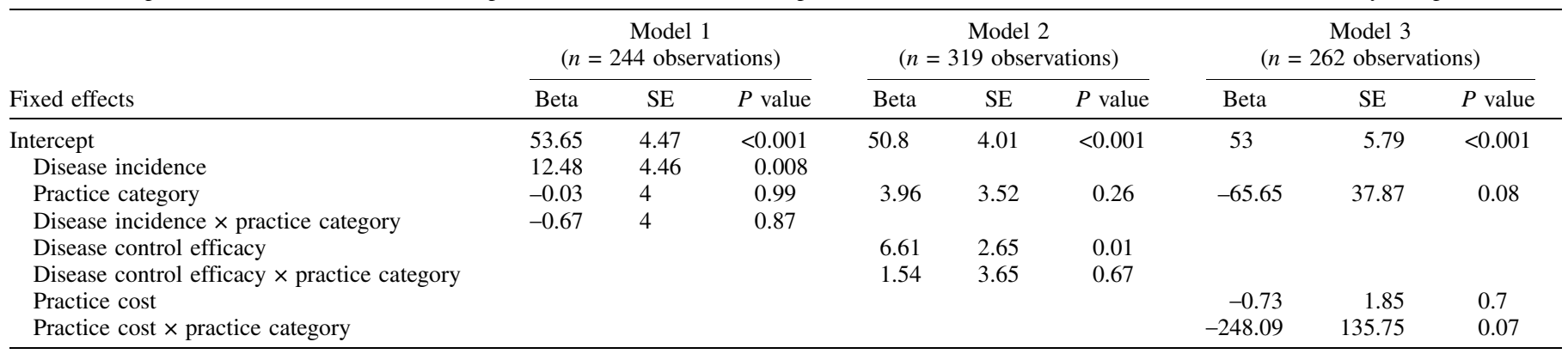

a Predictor variables are centered and standardized. $P$ values were calculated using Satterthwaite approximations to degrees of freedom. Random effects of respondent for each model were as follows: Model 1 variance $=385.7$, standard deviation $(\mathrm{SD})=30.83$; Model 2 variance $=482$, SD $=21.95$; and Model 3 variance $=590.1, \mathrm{SD}=24.29$. 
surgery, at least for controlling Eutypa dieback (Sosnowski et al. 2011). Also, the higher efficacy rating advisers gave to "protectanthand" compared with "protectant-tractor" is reported in the scientific literature, specifically for the fungicide carbendazime (Sosnowski et al. 2013). These findings are positive steps toward bridging the gap between academia and agriculture, and suggest that advisers have an important role in doing so.

We uncovered a positive association between recommendation rates and disease incidence, a pattern that was expected for postinfection practices. After all, "retrain trunk" is not necessary in vineyards with low disease incidence. We did not expect this pattern, however, for preventative practices; instead we expected to find either an inverse relationship between recommendation rate and disease incidence or high recommendation rates of preventative practices at all levels of disease incidence. Our finding that preventative practices are recommended more frequently in vineyards with high disease incidence suggests that advisers do not understand the importance of recommending their use in a truly preventative manner. On the other hand, advisers may be aware of the need for adopting preventative practices in vineyards with low disease incidence, but recommend otherwise for a variety of reasons, such as disinterest on the part of their clients in spending time and money on diseases that are not yet a serious problem. The influence of such financial incentives on advisers is outside the scope of this study, but the role of advisers, specifically those employed by pesticide companies, on grower decision making has been examined (Sherman and Gent 2014).

The incidence of symptoms due to the dieback-type diseases has been shown to increase exponentially between years 8 and 15 in susceptible 'Colombard' (Duthie et al. 1991), and therefore we assume that adopting preventative practices before year 8 minimizes the cumulative yield losses more significantly than doing so after year 15. Nonetheless, the symptoms of trunk diseases are not apparent typically until year 8 , when disease incidence reaches approximately 10\% (Duthie et al. 1991). Up to this point, yield losses are relatively minor (Munkvold et al. 1994). The impact of trunk diseases, therefore, can go unnoticed for $8+$ years. Low recommendation rates of preventative practices in vineyards with low disease incidence may therefore be a form of temporal discounting (Critchfield and Kollins 2001), in which advisers discount the future costs associated with trunk disease infection more strongly than the present costs of prevention. This temporal discounting is exacerbated by the uncertainty associated with the disease management decision-making environment (Marra et al. 2003), because advisers and growers do not know when their vineyards will eventually become infected. Additionally, many vineyards will not recoup the initial establishment costs until 7 years or later (J. Kaplan, R. Travadon, M. L. Cooper, V. Hillis, M. Lubell, and K. Baumgartner, unpublished data); under these conditions, growers have an incentive (or may be pressured by their lender) to minimize annual costs and begin making a return on their investment.

Recommendation rates of preventative practices may also be influenced by the fact that their benefits are more difficult to observe and accrue over longer periods of time than those of postinfection practices. Indeed, advisers gave a cost estimate to "replant specific vines" that was almost twice that of "double pruning" (the most costly preventative practice), yet they recommended the former $40 \%$ more frequently. Also, "sanitation" had the highest recommendation rate of all practices, even though advisers rated it last in terms of efficacy. Because the impacts of trunk diseases, in terms of disease incidence, yield losses, or lost years of profitability, for any particular vineyard are unknown, a grower using a preventative practice runs some risk of paying costs unnecessarily. Postinfection practices eliminate this risk because they are used only when a vineyard is already visibly infected. Given the relatively high recommendation rates of postinfection practices, despite their high costs, our results suggest that advisers may underestimate the future costs of failing to prevent trunk diseases. Advisers and growers who forego the relatively low, immediate cost of prevention inevitably face substantially higher costs associated with trunk disease infection, namely lost revenue (J. Kaplan, R. Travadon, M. L. Cooper, V. Hillis, M. Lubell, and K. Baumgartner, unpublished data).

Although preventative practices have been tested in many shortterm experimental trials (Rolshausen et al. 2010; Úrbez-Torres and Gubler 2011; Van Niekerk et al. 2011; Weber et al. 2007), their longterm efficacy has been the subject of far fewer studies ( $\mathrm{Gu}$ et al. 2005). Furthermore, all such studies measured efficacy in terms of recovery of the pathogen from treated pruning wounds or disease incidence (percent symptomatic vines). Such figures may be more meaningful to experts (i.e., researchers and extension personnel) than to growers; a similar gap in importance of technical information has been documented with respect to integrated weed management (Jabbour et al. 2013). Growers may thus be hesitant to adopt preventative practices before year 8 because improvements to yields and net returns have not been quantified.

It is also possible that growers do not believe the young vines are at risk of infection. This could be achieved by development of a novel method to rapidly detect the presence of spores of trunk pathogens in the vineyard or to predict which conditions favor spore
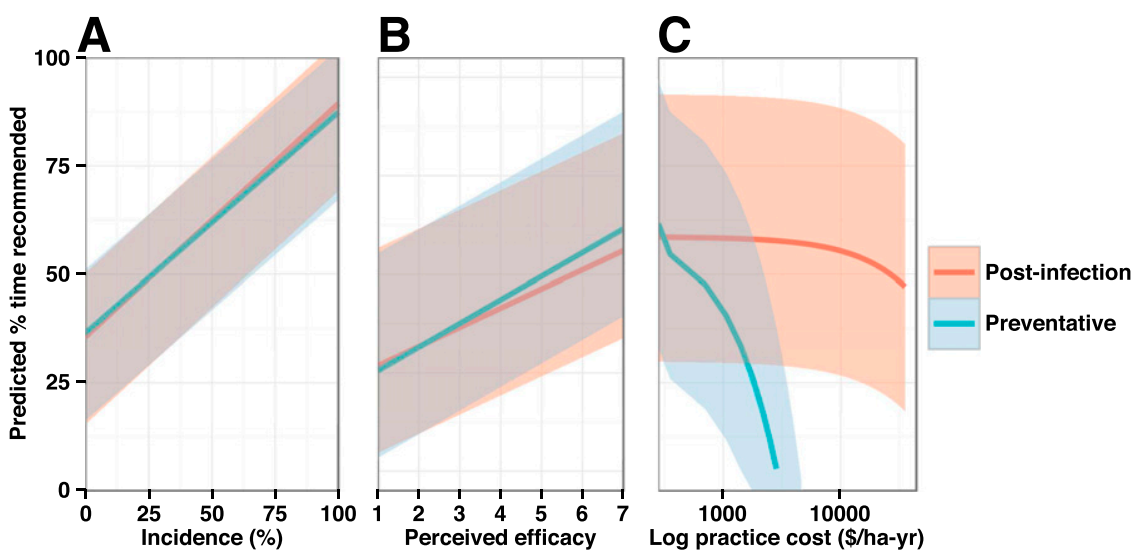

Fig. 5. Predicted relationships between recommendation rate and the following factors: A, disease incidence, B, perceived disease control efficacy (1 for very ineffective and 7 for very effective), and $\mathbf{C}$, estimated cost of practice ( $x$-axis plotted on a log scale in order to better visualize comparisons between practice categories, which are estimated at different orders of magnitude because "replanting whole block" is so much more expensive than all "preventative" practices). Relationships are plotted separately for preventative practices and postinfection practices (95\% confidence limits shown above and below each line), with substantial differences shown between these two categories for practice costs, but not for disease incidence or perceived disease control efficacy. 
germination and subsequent infection of pruning wounds. Other pathosystems have forecasting models (e.g., late blight of potato, e.g., SIMCAST [Grünwald et al. 2002]) and powdery mildew of grape (e.g., UC Davis Powdery Mildew Risk Index [Gubler et al. 1999]), which measure the risk of infection (and future disease impacts) based on climate conditions. As part of a decision-support system, such models have been shown to impact how growers manage fruit and foliar diseases by, for example, reducing the number of fungicide applications or replacing toxic fungicides with reduced-risk materials (Madden et al. 2007). Web-based decisionsupport systems that use location-specific climate data (e.g., BlightPro for potato and tomato late blight [Small et al. 2015]) have an even greater capacity to predict the risk of infection at the field level. In the case of trunk diseases, details on the effects of climate on the infection process, which build on the importance of rain in release of trunk pathogen spores (Úrbez-Torres et al. 2010), may advance development of decision-support systems. Notwithstanding the promise of such risk-assessment tools, it is important to note that complicated decision-support systems have thus far had mixed success in terms of their influence on adoption of preventative practices (McRoberts et al. 2011).

When timed properly, preventative practices are more efficient than postinfection practices in terms of cost. When they are used on a postinfection basis in vineyards with a high disease incidence, however, preventative practices are less efficient than postinfection practices in terms of efficacy. For example, applying fungicides to pruning wounds of a vine that is already infected is only minimally effective because the materials are protective; they are not known to have curative properties. Any impacts of such fungicide applications to health and human safety or to the environment, therefore, are not offset by improved vineyard productivity. In addition, because these fungicides are applied during the dormant (rainy) season, the potential for runoff is high. Indeed, chemical inputs in viticulture are associated with numerous environmental impacts, such as a decline in surface and groundwater quality (Hildebrandt et al. 2008). Adopting delayed pruning or double pruning is similarly ineffective if used on a postinfection basis; these practices are meant to prevent infection of pruning wounds by pruning during a period of low susceptibility (Petzoldt et al. 1981; Weber et al. 2007). Thus the cost of adopting such cultural practices after vines are already infected is not likely to be offset by significant disease reduction.

Some university publications and formal field trials verify the efficacy of preventative practices (Gu et al. 2005; Rolshausen et al. 2010). Despite our own finding that advisers prefer these information sources, our results do not suggest widespread adoption of preventative practices by growers. This gap between published research and vineyard practices can be addressed in the short term by modifying extension materials to explicitly state that preventative practices must be adopted in young vineyards before symptoms appear (Cooper et al. 2015). In the long term, outreach programs should target individuals in the agricultural knowledge network who play any kind of advisory role. As there are fewer grape advisers (approximately 1,000 [CAPCA, personal communication]) relative to the many grape growers (approximately 11,000 in California [Anonymous 2014]), an efficient strategy for outreach programs would target grape advisers.

Grapes, particularly wine grapes, are a relatively new and expanding crop in many regions of the New World and Australasia. National efforts in Australia have extended the importance of trunk disease prevention from lessons learned in established grape regions to help prevent similar disease outbreaks in nascent grape regions (Loschiavo et al. 2007). In California, the majority of acreage planted during the mid-to-late 1990s has matured to the age at which levels of trunk disease incidence are high. As these vineyards are being replanted, it is important to protect the new plantings and thus avoid the same mistakes, possibly through local outreach programs that target grape advisers and other individuals in the agricultural knowledge network who play any kind of advisory role. As in Australia, nationwide outreach in the United States to advisers in other states where similar grape species and wine grape cultivars are planted (e.g., Washington and Oregon) may benefit growers in these regions. In this way, expansion of vineyards outside of California can avoid economic losses by reducing uncertainty about the future risk of infection and future efficacy of preventative practices, whose benefits only accrue in the long run.

\section{ACKNOWLEDGMENTS}

Mention of trade names or commercial products is solely for the purpose of providing specific information and does not imply recommendation or endorsement by the U. S. Department of Agriculture. USDA is an equal opportunity provider and employer. We thank the California Association of Pest Control Advisers (CAPCA) for distributing the survey request via email to their members. D. Gates (Ridge Vineyards, Inc.), R. Smith (UCCE Farm Advisor, Sonoma County), C. Rogers (Paramount Farming Company, Lost Hills, CA), B. Higbee (Paramount Farming Company, Lost Hills, CA), L. Bettiga (UCCE Farm Advisor, Monterey County), and M. Hoffman (Lodi Winegrape Commission, Lodi, CA) provided recommendations and contact information for interviews. We also thank the UCCE Viticulture Farm advisors (S. Vasquez [Fresno County, CA], R. Smith [Sonoma County, CA], M. Cooper [Napa County, CA]), and the private PCAs and consultants (C. Rogers (Paramount Farming Company, Lost Hills, CA), Brad Higbee (Paramount Farming Company, Bakersfield, CA), L. Breyer [Breyer's Vineyard IPM Service, Windsor, CA], R. Loguloso [Frank A. Logoluso Farms, Firebaugh, CA], S. Zervas [Silverado Farming, Napa, CA]) who reviewed the survey during its development. We thank the individuals who provided their time to be interviewed as part of this research. We also thank R. Travadon (USDA-ARS, Davis, CA), M. Battany (UCCE Farm Advisor, San Luis Obispo and Santa Barbara counties), and P. Rolshausen (UCCE Specialist, University of California, Riverside) for comments on a version of this manuscript. This research was funded by grant 2012-51181-19954 to K. Baumgartner and M. Lubell from the USDA, National Institute of Food and Agriculture's Specialty Crops Research Initiative program.

\section{LITERATURE CITED}

Adesina, A. A., and Baidu-Forson, J. 1995. Farmers' perceptions and adoption of new agricultural technology: Evidence from analysis in Burkina Faso and Guinea, West Africa. Agric. Econ. 13:1-9.

Amponsah, N. T., Jones, E., Ridgway, H. J., and Jaspers, M. V. 2012. Evaluation of fungicides for the management of Botryosphaeria dieback diseases of grapevines. Pest Manag. Sci. 68:676-683.

Anderson, P. K., Cunningham, A. A., Patel, N. G., Morales, F. J., Epstein, P. R., and Daszak, P. 2004. Emerging infectious diseases of plants: Pathogen pollution, climate change and agrotechnology drivers. Trends Ecol. Evol. 19:535-544.

Anonymous. 2014. 2012 Census of Agriculture. U.S. Dept. Agric., National Agricultural Statistics Service, Washington, D.C.

Breukers, A., Van Asseldonk, M., Bremmer, J., and Beekman, V. 2012. Understanding growers' decisions to manage invasive pathogens at the farm level. Phytopathology 102:609-619.

Brodt, S. B., Goodell, P. B., Krebill-Prather, R. L., and Vargas, R. N. 2007. California cotton growers utilize integrated pest management. Calif. Agric. 61:24-30.

Bruez, E., Lecomte, P., Grosman, J., Doublet, B., Bertsch, C., Fontaine, F., Ugaglia, A., Teisedre, P.-L., Da Costa, J.-P., Guerin-Dubrana, L., and Rey, P. 2013. Overview of grapevine trunk diseases in France in the 2000s. Phytopathol. Mediterr. 52:262-275.

Cheatham, M. R., Rouse, M. N., Esker, P. D., Ignacio, S., Pradel, W., Raymundo, R., Sparks, A. H., Forbes, G. A., Gordon, T. R., and Garrett, K. A. 2009. Beyond yield: Plant disease in the context of ecosystem services. Phytopathology 99:1228-1236.

Cooper, M. L., Bettiga, L. J., Smith, R. J., Travadon, R., and Baumgartner, K. 2015. Guide to Trunk Diseases in California. Instructional Pamphlet. Integrated Pest Management Press, Division of Agriculture and Natural Resources, University of California.

Creemers, P. 2014. Anthracnose canker and perennial canker. Pages 51-53 in: Compendium of Apple and Pear Diseases and Pests. T. B. Sutton, H. S. Aldwinkle, A. M. Agnello, and J. F. Walgenbach, eds. The American Phytopathological Society, St. Paul, MN.

Critchfield, T. S., and Kollins, S. H. 2001. Temporal discounting: Basic research and the analysis of socially important behavior. J. Appl. Behav. Anal. 34:101-122. 
Duthie, J. A., Munkvold, G. P., and Marois, J. J. 1991. Relationship between age of vineyard and incidence of Eutypa dieback. (Abstr. 366) Phytopathology 81(suppl.):1183.

Feder, G., and Umali, D. L. 1993. The adoption of agricultural innovations: A review. Technol. Forecast. Soc. Change 43:215-239.

Grünwald, N. J., Montes, G. R., Saldana, H. L., Covarrubias, O. R., and Fry, W. E. 2002. Potato late blight management in the Toluca valley: Field validation of SimCast modified for cultivars with high field resistance. Plant Dis. 86:1163-1168.

Gu, S., Cochran, R. C., Du, G., Hakim, A., Fugelsang, K. C., Ledbetter, J., Ingles, C. A., and Verdegaal, P. S. 2005. Effect of training-pruning regimes on Eutypa dieback and performance of 'Cabernet Sauvignon' grapevines. J. Hortic. Sci. Biotechnol. 80:313-318.

Gubler, W. D., Rademacher, M. R., Vasquez, S. J., and Thomas, C. S. 1999. Control of powdery mildew using the UC Davis powdery mildew risk index. APSnet Features. Online. doi:10.1094/APSnetFeature-1999-0199

Halleen, F., Fourie, P. H., and Lombard, P. J. 2010. Protection of grapevine pruning wounds against Eutypa lata by biological and chemical methods. So. Afr. J. Enol. Vitic. 31:125-132.

Hildebrandt, A., Guillamón, M., Lacorte, S., Tauler, R., and Barceló, D. 2008. Impact of pesticides used in agriculture and vineyards to surface and groundwater quality (North Spain). Water Res. 42:3315-3326.

Hoffman, M., Lubell, M., and Hillis, V. 2015. Network-smart extension could catalyze social learning. Calif. Agric. 69:113-122.

Hurd, B. H. 1994. Yield response and production risk: An analysis of integrated pest management in cotton. J. Agric. Resour. Econ. 19:313-326.

Jabbour, R., Zwickle, S., Gallandt, E. R., Mcphee, K. E., Wilson, R. S., and Doohan, D. 2013. Mental models of organic weed management: Comparison of New England US farmer and expert models. Renew. Agric. Food Syst. 29:319-333.

Jacobsen, B. J. 1997. Role of plant pathology in integrated pest management. Annu. Rev. Phytopathol. 35:373-391.

Johnson, K. B., Pinkerton, J. N., Mehlenbacher, S. A., Stone, J. K., and Pscheidt, J. W. 1996. Eastern filbert blight of European Hazelnut: It's becoming a manageable disease. Plant Dis. 80:1308-1316.

Loschiavo, A., Sosnowski, M., and Wicks, T. 2007. Incidence of Eutypa dieback in the Adelaide Hills. Aus. New Z. Grapegrower Winemaker (April volume):26-29.

Lubell, M., Hillis, V., and Hoffman, M. 2011. Innovation, cooperation, and the perceived benefits and costs of sustainable agriculture practices. Ecol. Soc. 16:23.

Madden, L. V., Hughes, G., and Van Den Bosch, F. 2007. The Study of Plant Disease Epidemics. The American Phytopathological Society, St. Paul, MN.

Marra, M., Pannell, D. J., and Abadi Ghadim, A. 2003. The economics of risk, uncertainty and learning in the adoption of new agricultural technologies: Where are we on the learning curve? Agric. Syst. 75:215-234.

McRoberts, N., Hall, C., Madden, L. V., and Hughes, G. 2011. Perceptions of disease risk: From social construction of subjective judgments to rational decision making. Phytopathology 101:654-665.

Merenlender, A. M. 2000. Mapping vineyard expansion provides information on agriculture and the environment. Calif. Agric. 54:7-12.

Michailides, T. J., and Morgan, D. P. 2004. Panicle and shoot blight of pistachio: A major threat to the California pistachio industry. APSnet Features. Online. doi:10.1094/APSnetFeature-2004-0104

Munkvold, G. P., Duthie, A., and Marois, J. J. 1994. Reductions in yield and vegetative growth of grapevines due to Eutypa dieback. Phytopathology 84:186-192.

Oerke, E.-C. 2006. Crop losses to pests. J. Agric. Sci. 144:31-43.

Petzoldt, C. H., Moller, W. J., and Sall, M. A. 1981. Eutypa dieback of grapevine: Seasonal differences in infection and duration of susceptibility of pruning wounds. Phytopathology 71:540-543.

Pitt, W. M., Sosnowski, M. R., Huang, R., Qiu, Y., Steel, C. C., and Savocchia, S. 2012. Evaluation of fungicides for the management of Botryosphaeria canker of grapevines. Plant Dis. 96:1303-1308.
Prokopy, L. S., Floress, K., Klotthor-Weinkauf, D., and Baumgart-Getz, A. 2008. Determinants of agricultural best management practice adoption: Evidence from the literature. J. Soil Water Conserv. 63:300-311.

RCoreTeam. 2013. A Language and Environment for Statistical Computing. R Foundation for Statistical Computing, Vienna, Austria. http://www.Rproject.org/

Ridgley, A.-M., and Brush, S. 1992. Social factors and selective technology adoption: The case of integrated pest management. Hum. Organ. 51:367378.

Rogers, E. M. 2003. Diffusion of Innovations. 5th ed. Simon and Schuster, New York

Rolshausen, P. E., and Gubler, W. D. 2005. Use of boron for the control of Eutypa dieback of grapevines. Plant Dis. 89:734-738.

Rolshausen, P. E., Úrbez-Torres, J. R., Rooney-Latham, S., Eskalen, A., Smith, R. J., and Gubler, W. D. 2010. Evaluation of pruning wound susceptibility and protection against fungi associated with grapevine trunk diseases. Am. J. Enol. Vitic. 61:113-119.

Shennan, C., Cecchettini, C. L., Goldman, G. B., and Zalom, F. G. 2001. Profiles of California farmers by degree of IPM use as indicated by selfdescriptions in a phone survey. Agric. Ecosyst. Environ. 84:267-275.

Sherman, J., and Gent, D. H. 2014. Concepts of sustainability, motivations for pest management approaches, and implications for communicating change. Plant Dis. 98:1024-1035.

Siebert, J. B. 2001. Eutypa: The economic toll on vineyards. Wines and Vines (April) 2001:50-56.

Small, I. M., Joseph, L., and Fry, W. E. 2015. Development and implementation of the BlightPro decision support system for potato and tomato late blight management. Comput. Electron. Agric. 115:57-65.

Smyth, M., and Russell, J. 2009. 'From graft to bottle'-Analysis of energy use in viticulture and wine production and the potential for solar renewable technologies. Renew. Sustain. Energy Rev. 13:1985-1993.

Sosnowski, M. R., Creaser, M. L., Wicks, T. J., Lardner, R., and Scott, E. S. 2008. Protection of grapevine pruning wounds from infection by Eutypa lata. Aust. J. Grape Wine Res. 14:134-142.

Sosnowski, M. R., Loschiavo, A. P., Wicks, T. J., and Scott, E. S. 2013. Evaluating treatments and spray application for the protection of grapevine pruning wounds from infection by Eutypa lata. Plant Dis. 97:1599-1604.

Sosnowski, M. R., Wicks, T. J., and Scott, E. S. 2011. Control of Eutypa dieback in grapevines using remedial surgery. Phytopathol. Mediterr. 50: S277-S284.

Travadon, R., and Baumgartner, K. 2015. Molecular polymorphism and phenotypic diversity in the generalist, wood decay fungus Eutypa lata. Phytopathology 105:255-264.

Úrbez-Torres, J. R., Battany, M., Bettiga, L. J., Gispert, C., Mcgourty, G., Roncoroni, J., Smith, R. J., Verdegaal, P., and Gubler, W. D. 2010. Botryosphaeriaceae species spore-trapping studies in California vineyards. Plant Dis. 94:717-724.

Úrbez-Torres, J. R., and Gubler, W. D. 2011. Susceptibility of grapevine pruning wounds to infection by Lasiodiplodia theobromae and Neofusicoccum parvum. Plant Pathol. 60:261-270.

Úrbez-Torres, J. R., Leavitt, G. M., Voegel, T. M., and Gubler, W. D. 2006. Identification and distribution of Botryosphaeria spp. associated with grapevine cankers in California. Plant Dis. 90:1490-1503.

Van Niekerk, J. M., Halleen, F., and Fourie, P. H. 2011. Temporal susceptibility of grapevine pruning wounds to trunk pathogen infection in South African grapevines. Phytopathol. Mediterr. 50(suppl.):S139-S150.

Weber, E. A., Trouillas, F. P., and Gubler, W. D. 2007. Double pruning of grapevines: A cultural practice to reduce infections by Eutypa lata. Am. J. Enol. Vitic. 58:61-66.

Zalucki, M. P., Adamson, D., and Furlong, M. J. 2009. The future of IPM: Whither or wither? Aust. J. Entomol. 48:85-96. 